\title{
STOCK AND PASTURE MANAGEMENT ON HILL COUNTRY
}

\author{
J. A. H. INGLIS \\ "Ratahiwi", Woodville
}

At "Ratahiwi", we have endeavoured to apply the findings and observations of research workers and farmers, and to do some constructive thinking and observation of our own. We were fortunate in starting out with no appreciable liabilities, but more fortunate not to have spare cash; this gave us an incentive to make some. The human being is so constructed that he must have something against which to strive, in order to be happy. A farm can be developed indefinitely on a basis of maintaining profitability in relation to investment, which means that as the undertaking grows the total income must also grow. This process can give the satisfaction of achievement to the farmer and a better standard of living for his family. If farming in New Zealand was running at even half capacity, there would be no balance of payments problems.

A long time ago, we recognized that a person should be prepared to justify himself to himself for anything he does or believes, and also that there is always a better, easier, or cheaper way of doing anything which is to be done. This approach is more important than mere technical knowledge if a person wishes to progress in his chosen field of endeavour. Progressing from this line of thought, some sort of partnership can perhaps be more successful than the sole trader, as what one partner does not think of, the other often does.

This paper endeavours to pinpoint some of the ways that better-than-average results have been achieved from hill country pastoral farming. We run $53 \%$ ewes plus one hogget per acre, along with some cattle, and sell our surplus stock in condition for slaughter, while maintaining a smaller than usual labour force and keeping our cost structure low. We are far from having reached a limit, either in production per animal or per acre. Without doubt the most important single factor in development of pasture to high production is utilization.

We farm easy hill country, elevation 500 to $1,200 \mathrm{ft}$, with well-spread, reliable rainfall, 54 in. at the homestead, and higher on the slope of the Ruahine Ranges. The soils of two-thirds of the 1,150-acre farm are of alluvial pumiceous origin, with many wet parts, and one-third of greywacke derivatives, varying from boulders and rubble to patches of stiff grey soils. 
The original block of 850 acres has been in the family for many years, includes all the greywacke-derived soils, and was, in 1947, carrying 950 ewes, 400 dry sheep, and 30 cattle on fairly good utilization of pasture but a low plane of nutrition. Bidi-bidi, hard fern, sedges and toetoe were very common, and bracken and manuka occurred in patches. These have all gone under grazing management and topdressing. Rushes were and still are common. No drainage has yet been done.

One hundred acres were purchased in 1951, at least half covered with gorse and blackberry; this has been cleared by hose spraying only. A further hundred acres purchased 1964 had been a hill dairy farm, with pugged pastures and heavy infestation of buttercup; twelve months of sheep plus molybdic superphosphate have worked wonders. The last hundred acres were purchased this winter, and Tordon applied in June appears most successful on 20 acres of gorse and blackberry.

\section{Development}

The important thing in development is to do what is necessary to make the grass start growing, and to have the courage to put on the stock just before it grows. We have laws to guard our stock against ill treatment and starvation, although many people think it is kind to overfeed ewes and thus cause many deaths. The amount of cruelty and starvation which has been the lot of much land and pasture should be a matter for national concern.

In 1947, topdressing was started and in the period 1949 to 1957 all the easier discable country, 300 acres, was cultivated and resown, about $65 \%$ being accessible. All the farm which has not been sown down has been oversown with clovers. It is not desirable to topdress and oversow all a farm at once, as even if a farmer has sufficient money for the extra stock and fencing, it would be difficult to find anyone whose capabilities would be equal to the manage ment problems involved. In our own case, applications of $4 \mathrm{cwt}$ of superphosphate on old pasture, $5 \mathrm{cwt}$ with a follow-up at six months on new pasture, and then annual dressings reducing gradually to $2 \mathrm{cwt}$ at five years have been used with good effect. A slight fall in phosphate levels occurred over a six-year period of 2 cwt dressings, while stock numbers doubled. We are now stepping up to $4 \mathrm{cwt}$ superphosphate per annum. Molybdenum has been used three times since 1959 with outstanding results, and it will 
be used again next year. Had this element been in use earlier, results would have been better. Lime appears too expensive as an aerial application in proportion to its benefits, although our soils are acid.

The paddocks disced and sown in certified pastures gave a quick lift, but the old bush burn pastures with oversowing have caught up in production. Some new grass is a help in starting a farm going, but the uncultivable hill country is today a better proposition for a young farmer; it has the potential and is cheaper to buy. Our steeper, rocky country has been our most profitable when its original value is taken into account.

Cropping with choumoellier was tried and was not successful, no doubt owing to shortages of nitrogen and molybdenum. Dr P. D. Sears showed us how cropping of any sort is valuable if one wants to reduce fertility in a paddock, so it seems cruelty to the land to take crops from poor soil. Better surely to get the land into pasture, develop it by continuous stocking and reasonable topdressing so that the grass grows all the year round as ours now does. We could now grow winter crops, but when conditions become wet utilization is not satisfactory. Sheep do much better on actively growing pasture than on anything else, and it is much cheaper to grow. It is submitted that pasture growth in winter can be maintained up to 1,500 or 2,000 feet in the North Island. Our grass used.to be dormant from April till early October, but now it grows even in late July. Continuous utilization of the pasture by the grazing animal is far more important than the exact amount of fertilizer put on, although shortages of basic elements must be corrected. Our sheep are putting on the nitrogen equivalent of at least a ton of sulphate of ammonia per acre per annum, and our clovers give a similar amount. Clover rootlets die and the nitrogen in the nodules becomes available to the grasses at a rate in proportion to the frequency of grazing, so under continuous grazing much more nitrogen must be available in the ground. The clovers thrive on our management. This heavy dressing of nitrogen plus the rapid turnover of the other fertilizing elements, feeds the land. Nitrogen of course extends growth into cold or dry weather, so our normal dry periods of spring no longer bother us. In earlier days, green fertile patches caused by the excreta of sheep could be seen on the hills, but now the dark green colour is continuous.

From observation, it is suggested that cultivation and resowing of large open slopes of steep country is often inadvisable, except where scrub has to be removed. The 
take of grass is often poor owing to the law of gravity, aided by scouring and wind; the resultant smooth steep surface gives nowhere for stock to camp, so in effect the large steep face becomes what on a dairy farm is known as a day paddock, with its attendant low fertility.

Large trees cause a serious transference of fertility from the open pasture to the sheltered area, which is more serious than the weeds and germs which occur under the trees. If shelter trees can be proved to be necessary, they must give filtering of air, not wall or roof type protection, so that shelter will be long-reaching and there will be no inducement for stock to camp near the trees.

\section{Fencing}

Fencing is necessary for reasonable management 'of stock and utilization of pasture, but not too much should be done at first, until income is available from the farm. As income rises, the tax system is such that effective costs of development fall. Subject to any physical difficulties, the right size for a paddock is one which carries not more than 200 ewes through winter and lambing, and up to weaning. This makes for easy and efficient management, and is more important than acreage for its own sake. The right shape is that of a sheet of paper, which can be divided if necessary into two halves of the same shape. Some system of internal fenced lanes or roads to reach at least most paddocks is essential to efficient management of stock and utilization of labour. We have four good sets of sheepyards, and will build three more, and we have fifteen holding yards situated at suitable places where paddocks join. "Ratahiwi" is subdivided into 55 paddocks, and eleven more subdivisions are envisaged, largely on the recently acquired sections. Seven of these paddocks are of under ten acres and situated near the homestead. We originally worked on 40 acre subdivisions, then on a basis of 25 acres, but now as we expect to be able to run at least ten ewes per acre we think sizes of not over 20 acres are better.

The sheepyards save much driving of sheep, and the holding yards are valuable for docking, as sheep always run much more freely into a permanent yard than any temporary one.

\section{Stock}

We have looked at the land rather than the stock first, as the land is worth nearly three times as much as the live- 
stock, and it produces all the food for the stock which make our income. Without good stock husbandry, however, there can be no prosperity.

We hammered out the rough growth with steers, but our later development, that of increasing the number of plants per acre to give Levy's conception of a "carpet of grass", and making each plant grow faster, has been done by the grazing ewe on an increasing plane of nutrition. The ewe is a better developer than the hogget, the wether or the cattle beast, although some cattle must help utilization, and replacement ewes must be available.

Ewe hoggets are profitable in periods of high ewe prices, but to build up a farm the proportion of hoggets must be kept down. In the earlier 1950s, we ran an over proportion of hoggets, and made good income from them, but the pastures went ahead much better when we changed mostly to ewes with only enough hoggets for replacement. We have for some years been running half a ewe per acre extra each year; this increase, plus buying more land, has meant many bought-in ewes and no culling. We are not happy with the performance of the ewes we buy, so we are now increasing the proportion of Romney rams. At our present higher levels of stocking, the extra hoggets will give flexibility in winter management, and we should be able to continue increasing the vigour of our pastures.

One quarter of our ewes are Perendales, bought-in, mated with the Southdown, and run on the higher and less accessible country, where their thrift and ability to lamb themselves without assistance make them more profitable than the Romney, taking into account saving on shepherding costs. The Perendale could with advantage be used much more in New Zealand, but pastures may become too good for it. Perhaps a Romney comeback may replace it. It has been suggested that where a Romney flock is run and no lambs can be fattened, improved breeding and management or a change to Perendale is indicated, while if all Romney lambs fatten on the mothers, higher stocking or a change to, say, Leicester cross is possible. In the latter case, we would prefer more ewes.

We have been mating the worst third of our Romney ewes to the Southdown, and it has given some effective culling of the ewe flock. Now that soil fertility is higher, we will run fewer Southdowns but do not expect to eliminate them.

Big advances in the breeding potential of the Romney sheep are possible, and the better studs are taking up the challenge. Those flocks which have culled all ewes which 
have failed to rear a lamb and do it reasonably well have done a good service; now the stage is coming where rams will be selected on family histories of unassisted lambing. Compared to these advances, ability to produce twins is much less important ; on hill country many ewes fail to keep track of both lambs. If it were known that each ewe would produce one lamb only, and this without assistance one could run many more ewes and produce much more wool with less labour, but this may be asking too much of geneticists. There seems little benefit in improving genetic potential of sheep if constitution is lost and stocking rates have to be reduced to get production per sheep.

\section{Sheep Management}

Our management of sheep hinges on what has been termed set-stocking, but it is not the fixed carrying known in research establishments. We are first and foremost flexible, and "utilization stocking" is a better term for our practice. The aim is to have all paddocks stocked all the time, for the sake of both the stock and the pasture.

A year's management, starting in early July, our period of lowest stocking, will be surveyed briefly.

Hogegts are confined to their own paddocks at rates of nine or ten per acre, where we do not worry about a little autumn grown roughage. If not every paddock can be cleaned up, no bearing trouble will occur in the hoggets. We had two bearings in 6,500 ewes this year. Ewes are setstocked over all the rest of the farm, and a few will be moved from one paddock to another as feed indicates. The ewes eat nothing but fresh grass as it grows, and more or less maintain body weight - a slight fall in weight does no harm under set-stocking, and does reduce difficult births.

Lambing starts on August 20 to 25, and by mid September $85 \%$ of ewes have lambed. We then shed out all ewes without lambs, stock drys heavily where they will do most good to the pasture, keep springers handy, and of course drift the ewes with lambs out of some paddocks to make room for these.

Docking starts late in September when the lambs have reached immunity from arthritis. We then set-stock, and a few ewes with lambs will be drifted from one paddock to another as indicated. Lambs may be crutched in some paddocks from late November, and all will be crutched by weaning in December. Down-cross lambs are drafted, 35\% to works at weaning, and Romneys retained for grass con- 
trol. Grass is not spelled for weaning, although at times stock will be out of a paddock for some days. If a lamb can have as much as it likes to eat it will thrive and parasites do not matter much. This is achieved by putting lambs into short active pasture at about ten per acre, and letting it go gradually ahead of the lambs. When it becomes coarse, lambs can be shifted into another short paddock, and ewes and cattle put in to clean up. This gets away from ill-thrift when feed is soft from December to -May. Ewes are setstocked as far as possible at ten or fifteen per acre.

Some replacement ewes are bought in late January, and in February most remaining Down-cross lambs go to the works ; nearly all the tail-end go in March, when lambs may be reduced to eight per acre. Rams go out late in March, one per hundred ewes, and are left out for seven-and-a-half weeks. Most Romney wether lambs go to the works about early April, cull ewes to the works April or May. Last lambs go to the works in June, and aged ewes with reasonable teeth, run with ram, can be sold in June, or kept for lambing as feed dictates.

Shearing is done, all ewes, wet or dry, rams, and Romney lambs in January, ewe hoggets October, two-tooth ewes and any remaining Down-cross lambs in March.

One or two doses of thiabendazole are administered to hoggets, and one to two-tooth ewes before $M$ arch shearing. The only vaccination is ewes for pulpy kidney, rams for brucellosis. Elimination of mob stocking has improved sheep thrift, and reduced salmonella and footrot, while pasture utilization helps the footrot position.

\section{Results from Sheep}

Stocking on 1,150 acres this last winter and spring was 6,500 ewes, 70 rams, 1,000 hoggets, on grass only. Wool weights have increased from $12 \mathrm{lb}$ per acre to over $60 \mathrm{lb}$ for the last three years ( $661 \frac{1}{2} \mathrm{lb}$ last year); weights per sheep have increased, and quality of wool has greatly improved. Lambing percentages (Romney) have increased from 80 to about 100. We have gone from store farming to fattening all surplus stock. Health and vigour of sheep has increased, and diseases are presenting no problem. Ewe losses through lambing are now only about $1 \%$.

\section{Cattle}

As utilization by sheep has increased, fewer cattle are necessary, though about a hundred seem to be needed in 
autumn, and 60 or 70 through the rest of the year, except when it becomes very wet. This spring, we removed most of our 70 steers from pasture and fed them on hay for 25 days. This was most successful and will probably be repeated in wet springs. We expect to fatten the 21/2-year steers each year.

\section{Labour}

With under 1,000 acres and 5,000 ewes, the two partners, the writer and his sister, were happy doing all the work except fencing, shearing and winter ewe crutching. This year, with 1,150 acres and 6,500 ewes at the end of winter, we engaged a shepherd, and the three of us have not been overworked. Intelligent grazing greatly reduces the amount of work required at lambing.

We do not use horses. Motor cycles are regular transport except for wheel tractors at lambing. These latter enable us to carry our troubles with us, and assisted ewes can be dropped in the nearest yard to accept their lambs. The labour force of three has time available for fencing.

The farm is roaded fairly thoroughly now, and this enables much better utilization of our own time.

\section{Problems}

One must encounter problems as stocking rates are increased ; life would be dull with none.

Grass-grub has at present been eliminated, subterranean grass caterpillar is being controlled fairly well with summer applications of granular DDT superphosphate. but there is room for improvement in the control of this pest.

Some draining is envisaged, but it will be expensive owing to iron pans and boulders. Much of our wet soil cannot be drained because of broken contours, so rushes are likely to remain with us. Heavy grazing with cattle causes too much pugging, but some cattle do help to keep the rushes open. The ewes eat much rush in winter, and mowing on easier contours appears promising. It is possible that as we approach ten ewes per acre and do some draining the sheep may eat all the rushes, but a better approach may be that in which the Entomology Division of D.S.I.R. is currently interested. Most rushes in New Zealand are infested with the boring caterpillar of the moth, Glyphiteryx iochaeara, and while this does not give spectacular results it is possible there may be a hungrier relative. It is suggested that if "certified" strains of insects are ever bred, this might not be too difficult to accomplish. 
In favour of rushes, they are valuable for binding gullies, and as shelter for lambs, so control, not elimination, should be the aim.

\section{Finance}

Accounting figures are not included in this paper as it should be obvious we are running increasing numbers of sheep per acre, on rising production per animal, with low labour cost, low outlay on plant, no money wasted on cropping, while losses of stock are low. Therefore the profitability of our enterprise is satisfactory, and is increasing.

\section{DISCUSSION}

\section{Why are rams left out for $7 \%$ weeks?}

The cycle of a ewe is sixteen or seventeen days, say, two-and-a-half weeks ; we multiply this three times to give each ewe three chances.

\section{What is your vaccination policy for lambs?}

Lambs have never been vaccinated. Arthritis is troublesome if we dock too young,' say, under three weeks. Entcrotoxaemia (pulpy

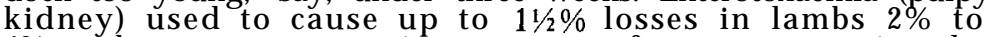
$4 \%$ weeks, so now we vaccinate thc ewes for enterotoxaemia only.

\section{Will net profit be higher when running 10 ewes per acre?}

Our intention is to go on increasing our stocking of ewes, but only as we make our pastures stronger. It is not our approach to feed the ewes harder; therefore our production per sheep should not drop, and our costs per ewe should be rather lower. At any given price level our net income should increase, but of course price variations will affect levels of profitability from season to season.

Has $\mathrm{Mr}$ Inglis observed different increases in production on different parts of the property relative to soil type?

Differences have been cbserved in relation to the amount of plant nutrients available on different parts of the farm, and the greywacke derivatives were poorer to start with. The same treatments have given similar increases over all parts.

Have ewe hoggets received any special treatment and what percentage of dry tw o-tooths are expected?

Through summer, autumn and early winter! hoggets are given preferential treatment by being stocked not thicker than the ewes; they eat less and therefore more choice is available.

We expect $5 \%$ of dry-dry two-tooths, the fraction being larger in bought ewes and lower in home-bred. This year we averaged $4 \frac{1}{2} \%$. 
Have you any burley grass problem and if so how do you prevent it seeding?

Barley grass is present, mostly associated with old trees, which latter are being eliminated. Under continuous grazing, there is considerable utilization of young seed heads. Spread of the grass is not great. When we fell all the trees we hope to start spraying.

Have the rows of trees been fenced off from grazing land?

Not of recent years. Fencing of big trees is difficult and expensive of maintenance; we prefer to use the chainsaw. Could the insecticide policy for control of grass-grub and sub-
terranean grass caterpillar be outlined?

We have tried cn a large scale:

(1) Soft DDT-superphosphate - good but prohibited now.

(2) Pelleted DDT-superphosphate.

(3) DDT prills.

(4) Diazinon pellets ("Gesapon").

On a small scale, wc have tried wet sprays of:

( 1) Diazinon ("Gesapon").

(2) Trichlorphon ("Diptcrex").

DIT mills were not satisfactory against subterranean grass caterpillar, while only DDT is effective against grass-grub. Costs of all treatments are comparable - the phosphate in DDT-super-phosphate is obtained at no extra cost. It is now policy to put DDT-superphosphate on two-thirds of the farm each year, sown from November to March.

\section{Did you apply copper when applying molybdenum?}

$\mathrm{No}$, it was unlikely to be needed. After the third dressing of molybdenum so many people asked about copper-shortage risks, I had the pasture tested; we can build up the molybdenum further without danger. Copper is low but molybdenum less than half as plentiful.

By increasing sheep numbers will you sacrifice constitution of ewes? No. Our sheep are gradually becoming stronger and production per ewe has not dropped. We breed with an eye to constitution.

In view of no provision for supplementing winter feed, do you experience sleepy sickness in ewes?

The worst we have had was about $1 / 2 \%$ one year. Our pastures are nourishing, and very little is needed to keep a ewe going. The key is'set-stocking. Most years, we have fewer than ten cases which appear to be pregnancy toxaemia.

Do mobs of over 200 ewes per paddock hamper production and efficiency ?

For efficiency in shepherding, and for kinder handling in yarding mobs, we do not like handling mobs of over 200 for lambing, docking, or up to weaning. The reduction in trampling during wet weather as well as more efficient grazing coverage do ejve some increase in carrying capacity per acre. Differences are not perhaps spectacular, and if physical difficulties hamper subdivision, most of our results can be achieved with larger mobs. 